\title{
PENGERTIAN FUNGSI DAN BIDANG GARAPAN MANAJEMEN SEKOLAH
}

\author{
KIKI ZAKIYAH \\ NIM 0142S1A018031 \\ STKIP Muhammadiyah Bogor \\ Zakiyahkiki48@gmail.com
}

\section{Pengertian Manajemen Sekolah}

Manajemen adalah metode yang digunakan administrator dalam melaksanakan tugas - tugas tertentu untuk mencapai tujuan tertentu. Manajemen pun dapat diartikan sebagai serangkaian cara yang dilakukan untuk menyelesaikan tugas demi terwujudnya tujuan organisasi.

Menurut Lawrence A. Appley dan Oey Liang Lee, dalam buku manajemen personalia (2014 : 16) yang ditulis nurzaman kadar, manajemen adalah strategi memanfaatkan tenaga dan pikiran orang lain untuk melaksanakan suatu aktifitas yang diarahkan pada pencapaian tujuan yang telah ditentukan sebelumnya.

Manajemen sekolah adalah serangkaian kegiatan pemanfaatan semua komponen baik komponen manusia maupun non manusia yang dimiliki sekolah dalam rangka mencapai tujuan yang efisien. Manajemen sekolah pun dapat diartikan sebagai proses atau rangkaian kegiatan yang telah disusun sebelumnya guna mencapai tujuan sekolah yang telah ditetapkan sebelumnya.

\section{Tujuan Manajemen Sekolah}

a. Meningkatkan mutu pendidikan melalui kemandirian dan inisiatif sekolah dalam mengelola dan memberdayakan sumber daya yang tersedia.

b. Meningkatkan kepedulian warga sekolah dan masyarakat dalam penyelenggaran pendidikan melalui pengambilan keputusan bersama.

c. Meningkatkan tanggung jawab sekolah kepada orangtua, masyarakat dan pemerintahan tentang mutu sekolah.

d. Meningkatkan kompetensi yang sehat antar sekolah dengan mutu pendidikan 
yang akan dicapai.

Inti tujuan manajemen sekolah adalah guna membantu pencapaian visi, misi, tujuan tahunan dan program-program sekolah.

\section{Fungsi Fungsi Manajemen Sekolah}

\section{1) Perencanaan (Planning)}

Perencanaan merupakan kegiatan untuk menetapkan tujuan yang akan dicapai beserta cara cara untuk mencapai tujuan tersebut. Sebagaimana disampaikan oleh T Hani Handoko (2005) menjelaskan bahwa "perencanaan (planning) adalah pemilihan atau penetapan tujuan organisasi dan penentuan strategi kebijakan proyek, program, prosedur, metode, dan sistem, anggaran dan standar yang dibutuhkan untuk mencapai tujuan.

T.Hani Handoko pun mengungkapkan terdapat empat tahap dalam perencanaan yaitu :

a. menetapakan tujuan atau serangkaian tujuan

b. merumuskan keadaan saat ini

c, mengidentifikasi segala kemudahan dan hambatan

e. mengembangkan rencana atau serangkaian kegiatan untuk pencapaian tujuan.

\section{2) Pengorganisasian (Organizing)}

Pengorganisasian pada dasarnya merupakan upaya untuk melengkapi rencana rencana yang telah dibuat dengan susunan prganisasi pelaksanaannya dan bagaimana semua itu mampu dilaksanakan dengan pembagian tugas dengan akhirnya target yang dapat tercapai dengan baik.

George R.Terry mengemukakan bahwa "pengorganisasian adalah tindakan mengusahakan hubungan hubungan kelakuan yang befektif antara orang orang, sehingga mereka dapat bekerja sama secara efisien, dan memperoleh kepuasan pribadi dalam melaksanakan tugas tugas tertentu, dalam kondisi lingkungan tertentu guna mencapai tujuan atau sasaran tertentu.

\section{3) Pelaksanaan ( Actuating)}

Pelaksanaan (actuating) merupakan upaya untuk menjadikan perencanaan 
menjadi kenyataan dan dapat terlaksana dengan baik, dengna melalui berbaagai pengarahan dan pemotivasian agar karyawan dapat melaksanakan tugas dengan maksimal sesuaia dengan tugas dan peran serta tanggung jawab yang sudah di berikan.

\section{4) Pengawasan ( Controling )}

Sebagaimana disampaiakan oleh T. Hani Handoko bahwa pengawasan manajemen adalah suatu usaha sistematik untuk menetapkan standar pelaksanaan dengan tujuan tujuan perencanaan, merancang sistem informasi umpan balik, membandingkan kegiatan nyata dengan standar yang telah ditetapkan sebelumnya, menentukan dan mengukur penyimpanan penyimpanan, serta mengambil tindakan koreksi yang diperlukan untuk menjamin bahwa semua sumber daya perusahaan dipergunakan dengan cara paling efektif dan efisisen dalam mencapai tujuan tujuan perusahaan.

Maka dapat ditarik kesimpulan bahwa pengawasan adalah proses pengendalaian terhadap pelaksaaan kegiatan yang telah direncanakan sebelumnya agar dapat sesuaia dengan dengan rencana dan pada akhirnya memastikan apakah tujuan organisasi tercapai secara baik atau tidak. Apabila terjadi penyimpangan maka diperlukan tindakan untuk dapat mengatasinya.

fungsi fungsi manajemen ini berkaitan satu dengan yang lainnya, maka ketika fungsi tersebut berjalan maka akan terjadinyanya proses manajamen yang mana proses manajemen ini tindakan interaksi satu individu dengan individu lainnya dalam sebuah organisasi untuk mencapai tujuan yang telah ditetapkan sebelumnya. Maka pada proses manajemen sekolah fungsi fungsi ini harus berjalan dengan baik agar semua proses pendidikan dapat terlaksana dengan baik sesuai fungsinya. Sehingga semua kegiatan kegiatan disekolah dapat terorganisir dengan baik.

\section{Bidang Bidang Garapan Manajemn Sekolah}

\section{A. Manajemen Kurikulum}

Kurikulum adalah seperangkat rencana dan pengaturan mengenai tujuan, isi dan bahan pelajaran serta bahan yang digunakan sebagai pedoman penyelenggaraan kegiatan pembelajaran untuk mencapai tujuan pendidikan tertentu (Rusman, 2009:3) 
Manajemen kurikulum adalah suatu sistem pengelolaan kurikulum yang koperatif, komperhensif, sistemik dan sistematik dalam rangka mewujudkan ketercapaian tujuan kurikulum.

Manajemen kurikulum merupakan substansi manajemen yang utama di sekolah. Prinsip dasar manajemen kurikulum ini adalah berusaha agar proses pembelajaran dapat berjalan dengan baik, dengan tolak ukur pencapaian tujuan oleh siswa dan mendorong guru untuk menyusun dan terus menerus menyempurnakan strategi pembelajaran.

\section{B. Manajemen Kesiswaan}

Manajemen kesiswaan adalah seluruh proses kegiatan yang direncanakan dan diusahakan secara sengaja serta pembinaan secara kontinyu terhadap seluruh peseta didik (dalam lembaga pendidikan yang bersangkutan) agar dapat mengikuti proses belajar mengajar secra efektif dan efisien. Manajemen kesiswaan juga merupakan proses pengurusan segala hal yang berkaitan dengan siswa mulai dari penerimaan peserta didik hingga keluarnya peserta didik dari suatu sekolah.

Fungsi pendidikan nasional yaitu mengembangkan kemampuan dan membentuk watak serta peradaban bangsa yang bermartabat dalam rangka mencerdaskan kehidupan bangsa, betujuan untuk berkembangnya potensi peserta didik agar menjadi manusia yang beriman dan bertaqwa kepada tuhan yang maha Esa, berakhlak mulia, sehat, berilmu, cakap, kreatif, mandiri, dan menjadi warga negara yang demokratis serta bertanggung jawab. Ini di laksanakan di manajemen kesiswaan karna dalam manajemen kesiswaan terdapat pembinaan terhadap siswa sesuai dengan fungsi pendidikan nasioanal.Pada bidang ini seluruh kegiatan siswa mulai dari pendisiplinan siswa dan sikap serta perilaku di laksanakan oleh bagian kesiswaan. Dalam manajemen kesiswaan terdapat empat prinsip dasar yaitu :

a. Siswa harus diperlakukan sebgai subyek dan bukan obyek, sehingga harus didorong untuk berperan serta dalam setiap perencanaan dan pengambilan keputusan yang terkait dengan kegiatan mereka.

b. Kondisi siswa sangat beragam, ditinjau dari kondisi fisik, kemampuan intelektual, social, ekonomi, minat dan seterusnya. Oleh karena itu diperlukan wahana kegiatan yang beragam. Sehingga setiapa siswa 
memiliki wahana untuk berkembang secara optimal.

c. Siswa hanya termotivasi belajar, jika mereka menyenangi apa yang diajarkan.

d. Pengembangan potensis siswa tidak hanya menyangkut ranah kognitif, tetapi juga ranah afektif, dan psikomotor.

Prinsip dasar diatas menjadi patokan utama bagi manajemen kesiwaan untuk bagaimana membina siswa dengan perbedaan yang mereka miliki.

\section{Manajemen Ketenagakerjaan/Personalia}

Manajemen ketenagerjaan adalah kegiatan perencanaaan, pengorganisasian pengarahan dan pengendalian atas pengadaan tenaga kerja, pengembangan, kompensasi, integrasi pemeliharaan, dan pemutus hubungan kerja dengan tenaga kependidikan untuk mencapai sasaran perorangan. Organisasi dan masyarakat.

Manajemn ketenagakerjaan sangat diperlukan karena manjemen ketenagakerjaan sangat diperlukan karena manajemn ketenagakerjaan dapat diartikan sebagai kegiatan perencanaan, pengadaan, pengembangan, pemeliharaan, dan penggunaan tenaga kependidikan dalam upaya mencapai tujuan individual maupun organisasi.

Manajemen ketenakerjaan ini lebih berfokus pada pendidik dan tenaga pendidik di sekolah dan semua yang berhubungan dengan penerimaan dan pemutusan hubungan kerja serta kinerja di kerjakan oleh manajemen ketenagakerjaan.

\section{Manajemen Keuangan}

Manajemen keuangan adalah kegiatan pengadaan dan pengelolaan dana keuangan yang memadai untuk kebutuhan pembangunan maupun kegiatan rutin operasional disekolah, serta cara sekolah mengadministrasikan dana tersebut dan cara melakukan pengawasan pengendalian serta pemeriksaan atas penggunaan dana tersebut.serta diperhatikan pula faktor akuntabilitas dan transparasi setiap penggunaan keuangan baik yang bersumber dari, pemerintah, masyarakat, donator maupun sumber- sumber yang lainnya.

\section{E. Manajemen Sarana Dan Prasarana}

Sarana pendidikan adalah semua peralatan atau perlengkapan yang 
digunakan dalam proses belajar mengajar dan dapat menunjnag untuk kegiatan tersebut, seperti, gedung, kelas, meja , kursi dan alat lainnya. Sedangkan prasarana adalah fasilitas yang secara tidak langsung menunjang jalannnya proses belajar mengajar, seperti, taman, kebun, lapangan dan lain sebagainya. Sarana prasaran juga sering disebut dengan fasilitas atau perlengkapan sekolah.

manajemen sarana prasarana menurut mulyono adalah seluruh proses kegiatan yang direncanakan dan diusahakan secara sengaja dan bersungguhsungguh serta pembinaan secara kontinu terhadap benda benda pendidikan, agar senantiasa siap dipakai dalam proses belajar mengajar.

Adapun manajemen sarana prasaran menurut Rohiat adalah kegiatan yang mengatur untuk mempersiapakan segala peralatan/materi bagi terselenggaranya proses pendidikan di sekolah. Dapat disimpul bahwa manajemen sarana prasarana merupakan keseluruhan proses perencanaan pengadaan, pendayagunaa, dan pengawasan sarana dan prasarana yang digunakan agar tjuan pendidikan disekolah dapat tercapai efektif dan efisien.

\section{F. Manajemen Humas}

Humas dapat diartikan sebagai kegiatan yang direncanakan menyangkut I'tikad baik, rasa simpati, saling mengerti untuk menegeroleh pengakuan penerimaan, dan dukunngan masyarakat melalui komunikasi untuk mendapatkan kesepakatan bersama. Komunikasi diartikan sebagai proses penyampaian pesan dari satu individu/ sumber ke pada orang lain.

Manajemen humas pendidikan disebut sebagai manajemen komunikasi pendidikan, yang dapat diartikan sebagai kegiatan hubungan antara sekolah dengan masyarakat sekolah, berisi tentang penyampaian informasi dan kerjasama demi keberlangsungan kegiatan dan keberadaan sekolah tersebut.

\section{G. Manajemen Ketatausahaan Dan Sistem Informasi}

The Liang Gie $(1998 ; 16)$ merumuskan pengertian tatausaha sebagai "segenap rangkaian aktivitas menghimpun, mencatat, mengolah, mengganda, menggirim, dan menyimpan keterangan-keterangan yang diperlukan dalam setiap organisasi”.

Manajemen ketatausahaan dan sistem informasi adalah kegiatan menghimpun segala keterangan yang diperlukan organisasi keumidan mencatat 
berbagai keterangan baik dalam bentuk tulisan maupun audio visual secara manual maupun elektronik sehingga dapat dibaca, dikirim,dan disimpan, serta mengolah berbagai keterangan keterangan yang telah dihimpun untuk dapat disajikan sebagai informasi yang bermanfaat bagi keberlangsungan disetiap kegiatan sekolah.

\section{Kesimpulan}

Manajemen sekolah adalah serangkaian kegiatan pemanfaatan semua komponen baik komponen manusia maupun non mausia yang dimiliki sekolah dalam rangka mencapai tujuan yang efisien.Dalam maanjemen sekolah terdapat 4 fungsi : a. fungsi perencanaan (Planning). b.Fungsi pengorganisasian (Organizing) c. Fungsi pelaksanaan ( Actuating ) d. Fungsi pengawasan ( Controling). Bidang bidang garapan manajemen sekolah dianataranya : Manajemen kurikulum, manajemen kesiswaan, manajemen keuangan, manajemen ketatausahaan dan sistem informasi, manajemen sapras, manajemen humas.

\section{Latihan Soal}

\section{I. pilihan ganda}

1. 'Manajemen adalah strategi mamanfaatkan tenaga dan pikiran oranglain untuk melaksanakan suatu aktifitas yang diarahkan pada pencapaian tujuan yang telah ditentukan sebelumnya” merupakan pegertian manajemen menurut..
a. The Liang Gie
c. sergiovanni
b. Lawrence A. Appley dan Oey Liang Lee
d. T.Hani Handoko

2. 'Manajemen sekolah dibentuk untuk membantu pencapaian visi, misi, tujuan tahunan dari program-program sekolah" itu merupakan
a. Tujuan manajemen sekolah
c. Prinsip manajemen sekolah 

c. Fungsi manajemen sekolah
d. Dasar manajemen sekolah

3. Tahapan pertama dalam fungsi manajemen adalah....
a. Pengorganisasian (organizing)
c. Pengawasan (Controling)
b. Perencanaan (Planning)
d. Pelaksanaan (Actuating)

4. "Perencanaan (Planning) adalah pemilihan atau penetapan tujuan organisasi dan penentuan strategi kebijakan proyek,program,prosedur,metode, dan sistem, anggaran dan standar yang dibutuhkan untuk mencapai tujuan.” Merupakan pengertian perencanaan menurut
a. The Liang Gie
c. T.Hani Handoko
b. Lawrence A. Appley dan Oey Laing Lee
d. George R.Terry

5. “Pengorganisasian adalah tindakan mengusahakan hubungan hubungan kelakuan yang efektif antara orang roang, sehingga mereka dapat bekerjasama secara efisien, dan memperoleh kepuasan pribadi dalam melaksanakan tugas tugas tertentu, dalam kondisi lingkungan tertentu guna mencapai tujuan atau sasaran tertentu.” Merupakan pengertian pengorganisasian yang dikemukakan oleh..
a. T. Hani Handoko
c. Lawrence A. Appley dan Oey Laing Lee
b. George R. Terry
d. sergiovani

6. Proses pengendalian pelaksanan kegiatan agar dapat berjalan sesuai yang direncanakan dan memastikan tujuan organisasi terlaksana dan tercapai dengan baik. Merupakan tugas dari fungsi..
a. Pengawas (Controling)
c. Pelaksanaan (Actuating)
b. Perencanaan (Planning)
d.
Pengorganisasian ( Organizing)

7. Tindakan interaksi dari individu ke individu lainnya dalam organisasi guna mencapai tujuan yang telah ditentukan. Merupakan pengertian dari..
a. Pelaksanaan organisasi
c. Skema Manajemen
b. Proses manajemen
d. Pembaharuan Manajemen

8. Berikut yang bukan termasuk bidang manajemen sekolah adalah
a. Manajemen kesiswaan
c. Manajemen ketatusahaan 

b. Manajemen Kurikulum
d. Manajemen perkantoran

9. Seperangkat rencana dan pengaturan mengenai tujuan, isi dan bahan pelajaran serta bagan yang digunakan sebagai pedoman penyelenggaraan kegiatan pembelajaran untuk mencapai tujuan pendidikan tertentu. Merupakan pengertian dari..
a. Tatausaha
c. Kurikulum
b. Visi Misi
d. Pedoman pembelajaran

10. Perencanaan, pengadaan pengecekan serta penghapusan barag- barang disekolah yang menunjang kepada proses pembelajaran dan kependidikan disekolah merupakan tugas dari..
A. Manajemen Keuangan
c. Bendahara Sekolah
B. Manajemen Kurikulum
d. Manajemen Sarana dan
Prasarana

\section{Essay}

1. Pengertian dari manajemen sekolah adalah..

2. Tujuan inti manajemen sekolah adalah..

3. Sebutkan fungsi-fungsi manajemen sekolah..

4. Pengertian manajemen kurikulum adalah..

5. Pengertian manajemen kesiswaan adalah..

Jawaban soal

\section{Pilihan ganda}

1. $B$

2. $\mathrm{C}$

3. $\mathrm{B}$ 
4. C

5. B

6. A

7. $B$

8. D

9. C

10. D

\section{Esaay}

1. Manajemen sekolah adalah serangkaian kegiatan pemanfaatan semua komponen baik komponen manusia maupun non manusia yang dimilki sekolah dalam rangka mencapai tujuan yang efisien.

2. Membantu pencapaian visi, misi, tujuan tahuan dan program-program sekolah.

3. A. Fungsi perencanaan ( Planning)

B..fungsi pengorganisasian (organizing)

C. Fungsi pelaksanaan (Actuating)

D. Fungsi Pengawasan (Controling)

4. Manajemen kurikulum adalah suatu sistem pengelolaan kurikulum yang koperatif, komperhensif,sistemik,sistematik dalam rangka mewujudkan ketercapaian tujuan kurikulum.

5. Manajemen kesiswaan adalah seluruh proses kegiatan yang direncanakan dan diusahakan secra sengaja serta pembinaan secara kontinu terhadap seluruh peserta didik (dalam lembaga pendidikan yang bersangkutan) agar dapat mengikuti proses belajar mengajar secara efektif dan efisien.

\section{DAFTAR PUSTAKA}

Sulfemi, Wahyu Bagja. (2018). Manajemen Kurikulum di Sekolah. Bogor : Visi 
Nusantara Maju.

Sulfemi, W. B. (2019). Manajemen Pendidikan Berbasis Multi Budaya. Bogor : STKIP Muhammadiyah Bogor.

Sulfemi, Wahyu Bagja. (2018). Modul Manajemen Pendidikan Non Formal. Bogor: STKIP Muhammadiyah Bogor.

https://teknologipendidikan2014.wordpress.com/2014/11/28/manajemenketenagaan/ https://samplingkuliah.blogspot.com/2017/04/manajemen-sarana-danprasarana.html

http://khotimhanifudinnajib.blogspot.com/2011/12/manajemen-humaspendidikan.html http://masykurpijay.blogspot.com/2011/01/administrasi-ketatausahaan-danstruktur.html 